\title{
Hubungan Pola Asuh Orang Tua Terhadap Kemandirian Anak Usia Dini Di TK Negeri Pembina Singkawang Timur
}

\author{
Dian Mayasari ${ }^{1}$, lip istirahayu ${ }^{2}$, Katarina Mawarni ${ }^{3}$ \\ STKIP Singkawang, Singkawang, Indonesia \\ diansingkawang@gmail.com ${ }^{1}$, iip_istirahayu@yahoo.com², katarinamawarni@yahoo.com ${ }^{3}$
}

\author{
Kata Kunci : \\ Pola Asuh Orangtua, \\ Kemandirian Anak Usia Dini
}

\begin{abstract}
ABSTRAK
Setiap pola asuh memiliki hubungan dan pengaruh terhadap dan karakter anak. Pola asuh orang tua memiliki hubungan terhadap kemampuan sosialisasi pada anak Pra Sekolah, terhadap konsep diri anak usia 10-12, terhadap kematangan emosi, terhadap Prestasi belajar, terhadap kepercayaan diri, terhadap perilaku sopan santun, terhadap motivasi belajar, dan terhadap Kemandirian anak. Tujuan penelitian ini adalah untuk mengetahui tingkat kemandirian anak usia dini di TK Negeri Pembina Singkawang dan hubungan pola asuh orang tua terhadap kemandirian anak usia dini. Penelitian ini merupakan penelitian kuantitatif dengan pendekatan korelasional. Sampel penelitian berjumlah 20 orang tua anak di TK Negeri Pembina Singkawang yang diambil secara acak yaitu dari Kelas TK B1 dan kelas TK B2. Pengumpulan data dalam penelitian ini menggunakan kuesioner. Analisis data yang digunakan adalah korelasi product moment. Tingkat kemandirian anak usia dini di TK Negeri Pembina Singkawang pada kategori sangat tinggi sebanyak 2 orang dengan persentase $20 \%$, kategori tinggi sebanyak 12 orang dengan persentase $60 \%$, kategori sedang sebanyak 6 orang dengan persentase 30\%, kategori rendah dengan persentase $0 \%$ dan kategori sangat rendah dengan persentase $0 \%$. Hasil perhitungan korelasi product moment menunjukkan rxy $=0,37$, hal ini menunjukkan terdapat hubungan antara pola asuh orang tua dengan kemandirian anak usia dini di TK Negeri Pembina Singkawang.
\end{abstract}

\section{PENDAHULUAN}

Setiap orang tua memiliki pola asuh yang berbeda. Terdapat beberapa macam tipe pola asuh orang tua dalam keluarga diantaranya adalah sebagai berikut: (a) gaya otoriter, (b) gaya demoktratis, (c) gaya laizes-faire, (d) gaya fathernalistik, (e) gaya karismatik, (f) gaya melebur diri, (g) gaya pelopor, (h) gaya manipulasi, (i) gaya transaksi, (j) gaya biar lambat asal selamat, (k) gaya alih peran, (l) gaya pamrih, (m) gaya tanpa pamrih, (n) gaya konsultan, (o) gaya militeristik, (Djamarah, 2014). Hasil penelitian juga menjelaskan bahwa bahwa pola asuh yang paling dominan dilakukan pada anak adalah 
pola asuh demokratis dan permisif. Pola asuh permisif cenderung memunculkan perilaku negatif pada anak, (Jannah, H., 2012). Pola asuh juga memberikan hubungan yang bermakna terdap tingkat depresi remaja (Safitri, Y., \& Hidayati, E., 2013).

Setiap pola asuh memiliki hubungan dan pengaruh terhadap dan karakter anak. Pola asuh orang tua memiliki hubungan terhadap kemampuan sosialisasi pada anak Pra Sekolah (Suharsono, J. T., Fitriyani, A., \& Upoyo, A. S. 2009), terhadap konsep diri anak usia 10-12 (Pramawaty, N., \& Hartati, E.,2012), terhadap kematangan emosi (Fellasari, F., \& Lestari, Y. I., 2017), terhadap Prestasi belajar (Agustiawati, I., 2014), terhadap kepercayaan diri (Longkutoy, N., Sinolungan, J., \& Opod, H., 2015), terhadap perilaku sopan santun (Risthantri, P., \& Sudrajat, A., 2015), terhadap motivasi belajar (Harianti, R., \& Amin, S., 2016), dan terhadap Kemandirian anak (Sunarty, K., 2016).

Kemandirian anak merupakan salah satu karakter yang harus di bangun sejak dini dan mulai dibentuk dari pola pengasuhan. Aspek perilaku kemandirian pada anak tidak hanya untuk kehidupan mereka pada saat di usia dini saja, tetapi juga berdampak bagi masa depan anak ketika sudah dewasa (Chairilsyah, D., 2019). Secara praktis kemandirian adalah kemampuan anak dalam berpikir dan melakukan sesuatu oleh diri mereka sendiri untuk memenuhi kebutuhannya sehingga mereka tidak lagi bergantung pada orang lain namun dapat menjadi individu yang dapat berdiri sendiri (Sa'diyah, R., 2017).

Ciri-ciri kemandirian diantaranya sebagai berikut: a) Kemandirian emosi, yaitu hubungan antara anak dan orang tua berubah dengan sangat cepat, lebih lebih setelah anak memasuki masa remaja. b) Kemandirian bertindak, yaitu mandiri dalam bertindak berarti bebas untuk bertindak sendiri tanpa terlalu bergantung pada bimbingan orang lain. c) Kemandirian berpikir merupakan proses yang paling kompleks tidak jelas bagaimana proses berlangsung dan pencapaianya terjadi melalui proses intralisasi yang pada lazimnya tidak disadari dan padaumumnya berkembang paling akhir dan paling sulit dicapai secara sempurna dibandingkan kedua tipe kemandirian lainnya (Eti, N., 2011).

Untuk membangun kemandirian anak, perlu di ukur tingkat kemandirian anak. Informasi sejak dini tentang anak dapat dijadikan dasar dalam memberikan informasi kepada para orang tua terkait pola asuh yang tepat untuk membangun karakter anak, khususnya kemandirian mereka.

\section{METODE}

Penelitian ini menggunakan data tipe penelitian kuantitatif. Penelitian kuantitatif adalah penelitian yang difokuskan pada kajian fenomena objektif untuk dikaji secara kuantitatif. Untuk itu, teknik yang digunakan adalah korelasi analisis sederhana. teknik pengumpulan data dalam suatu penelitian adalah Angket atau kuesioner (questionnaires) Dalam penelitian ini yang menjadi populasi adalah orang tua siswa dan diambil secara acak atau random sebanyak 20 orang tua siswa sebagai sampel penelitian. (Arikunto, S., 2010)

Dalam penelitian ini, peneliti menggunakan perhitungan korelasi Product Moment sederhana, yaitu hubungan antara satu variabel independen dan satu dependen. Setiap pernyataan dari kedua skala penilaian tersebut memiliki empat alternatif pilihan jawaban, yaitu Sangat Setuju (SS), (KS), Kurang Setuju (TS), T idak Setuju (STS), Sangat Tidak Setuju. Selanjutnya melakukan uji kelayakan. Diperoleh pernyataan sebanyak 40 pernyataan dan 20 kemandirian anak usia dini dan 20 pernyatan pola asuh. (Saifuddin. A., 2001). Teknis analisis data yang digunakan untuk mengetahui hubungan pola asuh orang tua terhadap kemandirian anak usia dini di TK Negeri Pembina Singkawang Timur menggunakan rumus Korelasi person product moment. (Sudjana, N., 2009) 
Journal of Educational Review and Research

Vol. 3 No. 2, December 2020: 111 - 115

e-ISSN: 2597-9760, p-ISSN: 2597-9752

\section{HASIL DAN PEMBAHASAN}

HASIL

Di bawah ini adalah gambaran tingkat kemandirian anak usia dini di TK Pembina Singkawang

Tabel 1. Kemandirian Anak Usia Dini

\begin{tabular}{llll}
\hline No & Kategori & Frekwensi & Persentase \\
\hline 1 & Sangat Tinggi & 7 & $35 \%$ \\
2 & Tinggi & 12 & $60 \%$ \\
3 & Cukup/ sedang & 1 & $5 \%$ \\
4 & Rendah & 0 & 0 \\
5 & Sangat Rendah & 0 & 0 \\
Jumlah & & 20 & $100 \%$ \\
\hline
\end{tabular}

Dari tabel di atas dapat dijelaskan bahwa sebesar 35\% anak usia dini di Tk pembina Singkawang Timur memiliki kemandirian yang sangat tinggi, sebesar 60\% memiliki kemadirian tinggi, dan hanya 5\% yang cukup memiliki kemandirian. Selanjutnya, tidak ada anak yang tidak mandiri dan tidak ada anak yang memiliki kemandirian rendah. Artinya, setaip anak di Tk pembina Singkawang memiliki kemandiarian cukup, tinggi, dan sangat tinggi.

Dari gambaran tingkat kemandirian yang diperoleh, maka perhitungan korelasi menggunakan analisis produck moment menunjukkan angka sebesar 0.37. artinya, angka tersebut menjelaskan bahwa terdapat hubungan antara antara pola asuh orang tua terhadap kemandirian anak usia dini di TK Pembina Singkawang.

\section{PEMBAHASAN}

Dari Hasil penelitian yang di peroleh dengan rumus diatas dapat dijelaskan tingkat Hubungan Variabel $\mathrm{x}$ dan Variabel $\mathrm{y}$, dan pada hakikatnya variabel $\mathrm{r}$ dapat bervariasi dari -1 hingga +1 bila $\mathrm{r}=0$ atau mendekati 0 , maka korelasi antara dua variabel lemah atau tidak terdapat hubungan antara variabel $\mathrm{X}$ dan variabel Y, bahwa terdapat hasil Hubungan pola asuh orang Tua Terhadap Kemandirian anak Usia Dini di TK Negeri Pembina Singkawang Timur. Penelitian ini tidak jauh berbeda dengan penelitian sebelumnya yang menjelaskan bahwa terdapat hubungan pola asuh orang tua terhadap kemandirian belajar anak (Jayantini, N. M. S., Made Sulastri, M. P., \& Sedanayasa, G., 2014).

Adanya hubungan antar kedua variabel pola asuh dan kemandirian dapat dijadikan sebagai strategi dalam mempersiapkan pola asuh dan kemandirian anak. Seperti penelitian yang telah dilakukan, menyatakan bahwa membentuk kemandirian anak melalui penggunaan pola asuh, pemberian contoh dan pendampingan pada anak dalam mengerjakan aktivitas yang bisa dilakukan anak secara mandiri, serta membiasakan anak untuk melakukan aktivitas sederhana sehari-hari untuk memenuhi kebutuhan diri sendiri (Affrida, E. N., 2017). Selain itu, kemandirian anak juga dapat ditingkatkan melalui Pembelajaran Practical Life (Rantina, M., 2015), dan kemandirian dapat berkembang sesuai harapan (BSH), dan Mulai Berkembang (MB) (Khotijah, I., 2018).

Penelitian lainnya menjelaskan bahwa melalui pembelajaran di sentra bahan alam dapat meningkatkan kemandirian anak.Disarankan pada pendidik dapat menggunakan kegiatan pembelajaran sentra bahan alam untuk dapat meningkatkan kemandirian anak karena dengan kegiatan sentra bahan alam anak dapat bereksplorasi dengan alam sehingga anak menjadi berani, percaya diri,bertanggung jawab dan mandiri (Sari, W., 2016). 


\section{KESIMPULAN DAN SARAN}

Tingkat kemandirian anak usia dini di TK Negeri Pembina Singkawang pada kategori sangat tinggi sebanyak 2 orang dengan persentase $20 \%$, kategori tinggi sebanyak 12 orang dengan persentase $60 \%$, kategori sedang sebanyak 6 orang dengan persentase $30 \%$, kategori rendah dengan persentase $0 \%$ dan kategori sangat rendah dengan persentase $0 \%$. Terdapat hubungan antara pola asuh orang tua dengan kemandirian anak usia dini di TK Negeri Pembina Singkawang.

Diharapkan para orang tua dapat mengenali karakteristik anak, sehingga dapat menentukan pola asuh yang memberikan dampak positif bagi perkembangan serta pembentukan karakter bagi anak.

\section{DAFTAR PUSTAKA}

Affrida, E. N. (2017). Strategi Ibu dengan Peran Ganda dalam Membentuk Kemandirian Anak Usia Pra Sekolah. Jurnal Obsesi: Jurnal Pendidikan Anak Usia Dini, 1(2), 114-130.

Agustiawati, I. (2014). Pengaruh pola asuh orang tua terhadap prestasi belajar siswa pada mata pelajaran akuntansi kelas XI IPS di SMA Negeri 26 Bandung (Doctoral dissertation, Universitas Pendidikan Indonesia).

Arikunto, S. (2010). Prosedur Penelitian. Jakarta: Rineka Cipta. Edisi II.

Chairilsyah, D. (2019). Analisis Kemandirian Anak Usia Dini. PAUD Lectura: Jurnal Pendidikan Anak Usia Dini, 3(01), 88-98.

Djamarah. (2014). Pola Asuh Orang Tua Dan Komunikasi DalamKeluarga.Jakarta: Rineka Cipta.

Eti, N. (2011). Psikologi Pendidikan Inovatif, Yogyakarta : Pustaka Pelajar.

Fellasari, F., \& Lestari, Y. I. (2017). Hubungan antara pola asuh orangtua dengan kematangan emosi remaja. Jurnal Psikologi, 12(2), 84-90.

Harianti, R., \& Amin, S. (2016). Pola asuh orangtua dan lingkungan pembelajaran terhadap motivasi belajar siswa. Curricula: Journal of Teaching and Learning, 1(2).

Jannah, H. (2012). Bentuk pola asuh orang tua dalam menanamkan perilaku moral pada anak usia di kecamatan ampek angkek. Jurnal Ilmiah Pesona PAUD, 1(2).

Jayantini, N. M. S., Made Sulastri, M. P., \& Sedanayasa, G. (2014). Hubungan pola asuh orang tua terhadap kemandirian belajar siswa kelas XI SMA Negeri 1 Sukasada tahun pelajaran 2013/2014. Jurnal Ilmiah Bimbingan Konseling Undiksha, 2(1).

Khotijah, I. (2018). Peningkatan kemandirian anak melalui pembelajaran practical life. Jurnal Golden Age, 2(02), 127-140.

Longkutoy, N., Sinolungan, J., \& Opod, H. (2015). Hubungan pola asuh orang tua dengan kepercayaan diri siswa SMP Kristen Ranotongkor kabupaten Minahasa. eBiomedik, 3(1).

Pramawaty, N., \& Hartati, E. (2012). Hubungan pola asuh orang tua dengan konsep diri anak usia sekolah (10-12 tahun). Jurnal Keperawatan Diponegoro, 1(1), 87-92. 
Rantina, M. (2015). Peningkatan Kemandirian Melalui Kegiatan Pembelajaran practical Life. Jurnal Pendidikan Usia Dini, 9(1), 181-200.

Risthantri, P., \& Sudrajat, A. (2015). Hubungan antara pola asuh orang tua dan ketaatan beribadah dengan perilaku sopan santun peserta didik. Harmoni Sosial: Jurnal Pendidikan IPS, 2(2), $191-202$

Safitri, Y., \& Hidayati, E. (2013). Hubungan Antara Pola Asuh Orang Tua Dengan Tingkat Depresi Remaja di SMK 10 November Semarang. Jurnal Keperawatan Jiwa, l(1).

Saifuddin. A. (2001). Metode Penelitian. Yogyakarta: Pustaka Pelajar Offset.

Sari, W. (2016). Meningkatkan Kemandirian Anak Di Sentra Bahan Alam Pada TK Bunga Mekar Kecamatan Seulimeum Kabupaten Aceh Besar. Jurnal Ilmiah Mahasiswa Pendidikan Anak Usia Dini, 1(1).

Sa'diyah, R. (2017). Pentingnya melatih kemandirian anak. Kordinat $\mid$ Jurnal Komunikasi Antar Perguruan Tinggi Agama Islam, 16(1), 31-46.

Sudjana, N. (1990). Penilaian Hasil Proses Belajar Mengajar. Bandung: Remaja Rosdakarya.

Suharsono, J. T., Fitriyani, A., \& Upoyo, A. S. (2009). Hubungan pola asuh orang tua terhadap kemampuan sosialisasi pada anak prasekolah di TK Pertiwi Purwokerto Utara. Jurnal keperawatan soedirman, 4(3), 112-118.

Sunarty, K. (2016). Hubungan Pola Asuh Orangtua Dan Kemandirian Anak. Journal of Educational Science and Technology (EST), 2(3), 152-160. 